TANTANGAN PENDIDIK DI ERA DIGITAL

\title{
Diplan $^{1}$
}

\author{
1. Universitas Muhammadiyah Palangkaraya \\ diplan161181@gmail.com
}

\begin{abstract}
ABSTRAK
Di era globalisasi dan informasi ini, guru dan dosen mendapatkan tantangan berupa perilaku siswa yang senang berselancar di dunia maya melalui android, gadget atau handphone canggih yang mereka miliki. Perilaku siswa ini ditandai oleh adanya kecendrungan lebih senang membaca melalui handphone ketimbang buku, senang mencari berbagai informasi sendiri tanpa melakukan recheck lebih dahulu, senang mencari teman melalui akun media sosial, dan terkesan individualis. Untuk itu, guru dan dosen dalam pembelajaran harus mampu memanfaatkan Teknologi Informasi, menggunakan metode yang menyenangkan, memperkaya keilmuan dengan berbagai sumber bahan bacaan, dan mampu melakukan penelitian. Demikian uraian yang berkaitan dengan tantangan pendidik di era Millennial dan upaya yang dilakukan untuk mencari solusi terhadap tantangan yang dihadapi guru.
\end{abstract}

Kata Kunci: Era Digital, Pendidik, Milennial

\section{PENDAHULUAN}

Sejarah revolusi industri dimulai dari industri 1.0, 2.0, 3.0, hingga industri 4.0. Industri 1.0 ditandai dengan mekanisasi produksi untuk menunjang efektifitas dan efisiensi aktivitas manusia, industri 2.0 dicirikan oleh produksi massal dan standarisasi mutu, industri 3.0 ditandai dengan penyesuaian massal dan fleksibilitas berbasis otomasi dan robot. Industri 4.0 selanjutnya hadir menggantikan industri 3.0 yang ditandai dengan penggabungan mesin, alur kerja, dan sistem, dengan menerapkan jaringan cerdas. Istilah industri 4.0 berasal dari sebuah proyek yang diprakarsai oleh pemerintah Jerman untuk mempromosikan komputerisasi diberbagai bidang.

Lee et al (2013) menjelaskan, industri 4.0 ditandai dengan peningkatan digitalisasi yang didorong oleh empat faktor: 1) peningkatan volume data, kekuatan komputasi, dan konektivitas; 2) munculnya analisis, kemampuan, dan kecerdasan bisnis; 3) terjadinya bentuk interaksi baru antara manusia dengan mesin; dan 4) perbaikan instruksi transfer digital ke dunia fisik, seperti robotika dan 3D printing. Lifter dan Tschiener (2013) menambahkan, prinsip dasar industri 4.0 adalah penggabungan mesin, alur kerja, dan sistem, dengan menerapkan jaringan cerdas di sepanjang rantai dan proses produksi untuk mengendalikan satu sama lain secara mandiri.

Hermann et al (2016) menambahkan, ada empat desain prinsip industri 4.0. Pertama, interkoneksi (sambungan) yaitu kemampuan mesin, perangkat, sensor, dan orang untuk terhubung dan berkomunikasi satu sama lain melalui Internet of Things (IoT) atau Internet of People (IoP). Prinsip ini membutuhkan kolaborasi, keamanan, dan standar. Kedua, transparansi informasi merupakan kemampuan sistem informasi untuk menciptakan salinan virtual dunia fisik dengan 
memperkaya model digital dengan data sensor termasuk analisis data dan penyediaan informasi. Ketiga, bantuan teknis yang meliputi; (a) kemampuan sistem bantuan untuk mendukung manusia dengan menggabungkan dan mengevaluasi informasi secara sadar untuk membuat keputusan yang tepat dan memecahkan masalah mendesak dalam waktu singkat; (b) kemampuan sistem untuk mendukung manusia dengan melakukan berbagai tugas yang tidak menyenangkan, terlalu melelahkan, atau tidak aman; (c) meliputi bantuan visual dan fisik. Keempat, keputusan terdesentralisasi yang merupakan kemampuan sistem fisik maya untuk membuat keputusan sendiri dan menjalankan tugas seefektif mungkin.

Industri 4.0 telah memperkenalkan teknologi produksi massal yang fleksibel (Kagermann et al, 2013). Mesin akan beroperasi secara independen atau berkoordinasi dengan manusia (Sung, 2017). Industri 4.0 merupakan sebuah pendekatan untuk mengontrol proses produksi dengan melakukan sinkronisasi waktu dengan melakukan penyatuan dan penyesuaian produksi (Kohler \& Weisz, 2016). Selanjutnya, Zesulka et al (2016) menambahkan, industri 4.0 digunakan pada tiga faktor yang saling terkait yaitu; 1) digitalisasi dan interaksi ekonomi dengan teknik sederhana menuju jaringan ekonomi dengan teknik kompleks; 2) digitalisasi produk dan layanan; dan 3) model pasar baru. Baur dan Wee (2015) memetakan industri 4.0 dengan istilah "kompas digital"

Kompas Digital merupakan instrumen bagi perusahaan dalam mengimplementasikan industri 4.0 agar sesuai dengan kebutuhan mereka. Pada komponen tenaga kerja (labor), harus memenuhi; 1) kolaborasi manusia dengan robot; 2) kontrol dan kendali jarak jauh; 3) manajemen kinerja digital; dan 4) otomasi pengetahuan kerja. Demikian pula pada komponen lainnya digunakan sebagai instrumen implementasi industri 4.0.

Revolusi digital dan era disrupsi teknologi adalah istilah lain dari industri 4.0. Disebut revolusi digital karena terjadinya proliferasi komputer dan otomatisasi pencatatan di semua bidang. Industri 4.0 dikatakan era disrupsi teknologi karena otomatisasi dan konektivitas di sebuah bidang akan membuat pergerakan dunia industri dan persaingan kerja menjadi tidak linear. Salah satu karakteristik unik dari industri 4.0 adalah pengaplikasian kecerdasan buatan atau artificial intelligence (Tjandrawinata, 2016). Salah satu bentuk pengaplikasian tersebut adalah penggunaan robot untuk menggantikan tenaga manusia sehingga lebih murah, efektif, dan efisien.

Unsur-unsur pendidikan dalam definisi di atas terdiri dari usaha (kegiatan) yang bersifat bimbingan dan dilakukan secara sadar, pendidik (pembimbing), anak didik, dasar dan tujuan, dan alat-alat yang digunakan dalama usaha itu. Dengan demikian dapatlah dikatakan bahwa pendidikan sebagai sebuah sistem terdiri dari tujuan, metode, materi (kurikulum), pendidik, anak didik, alat pendidikan, dan lingkungan. Semua unsur ini saling berkaitan satu sama lain. Pendidikan saat ini menghadapi berbagai tantangan, antar lain bisa dilihat dari karakter anak. Karakter anak zaman now semakin nyeleneh dan semaunya sendiri. Anak-anak cenderung egois, tidak suka bekerja sama. Hal ini disebabkan seringnya mereka lebih suka bermain game lewat ponsel android daripada permainan tradisional yang mengajarkan perilaku untuk bekerjasama. Fenomena ini tidak bisa dipungkiri, baik itu di kota maupun di pelosok desa sekalipun. Karakter anak pada sebagian generasi millenial memprihatinkan. Mereka kadang tidak menghargai 
orangtua maupun gurunya. Bahkan dari mereka juga terkadang terjebak pada dunia criminal dan narkoba. Generasi millenial dalam minat belajar juga sebagian besar mengalami kemunduran. Di era millennial, kecenderungan dunia pendidikan antara lain: berkembangnya model belajar jarak jauh (Distance Learning), mudahnya menyelenggarakan pendidikan terbuka, sharing resource bersama antar lembaga pendidikan, perpustakaan dan instrument pendidikan lainnya (guru, dosen, laboratorium) berubah fungsi menjadi sumber informasi daripada sekedar rak buku. Lembaga pendidikan akan menghadapi sebuah perubahan yang signifikan akibat proses digital ini. Ini menjadi sebuah peluang dan cara untuk meningkatkan kualitas pendidikan sekaligus tantangan bagi dunia pendidikan di Indonesia. Pada era millenial, manusia mulai meninggalkan cara-cara konvensional dalam menjalani kehidupan, digantikan dengan trend dan gaya hidup yang lebih fresh and youth, atau yang biasa dikenal dengan istilah "kekinian". Seorang aktivisi HMI, Muhammad Ridal, dalam bukunya yang berjudul "HMI Millenial" mengungkapkan bahwa 33\% masyarakat Indonesia saat ini merupakan generasi millenial. Menurut Ridal, era millenial umumnya didominasi oleh orang-orang kelahiran tahun 1980 sampai tahun 2000an, dan berusia 15-34 tahun. Usia ini, tentu saja, merupakan usia dimana individu masih berstatus sebagai pelajar di sekolah.

\section{PEMBAHASAN}

\section{A. Karakteristik Generasi Milennial}

Generasi millennial memiliki beberapa karakteristik, yaitu: 1. Millennial tidak percaya lagi kepada distribusi informasi yang bersifat satu arah. Mereka lebih percaya kepada konten dan informasi yang dibuat oleh perorangan. Dalam hal pola konsumsi, banyak dari mereka memutuskan untuk membeli produk setelah melihat review atau testimoni yang dilakukan oleh orang lain di internet. Mereka juga tak segan-segan membagikan pengalaman buruk mereka terhadap suatu merek. 2. Millennial lebih memilih ponsel dibanding TV. Televisi bukanlah prioritas generasi millennial untuk mendapatkan informasi atau melihat iklan. Generasi millennial lebih suka mendapat informasi dari ponselnya, dengan mencarinya ke Google atau perbincangan pada forum-forum yang mereka ikuti. 3 . Millennial wajib punya media sosial. Komunikasi di antara generasi millennial sangatlah lancar. Komunikasi itu tidak selalu terjadi dengan tatap muka. Banyak dari mereka melakukan semua komunikasinya melalui text messaging atau juga chatting di dunia maya, dengan membuat akun yang berisikan profil dirinya, seperti Twitter, Facebook, hingga Line. Akun media sosial juga dapat dijadikan tempat untuk aktualisasi diri dan ekspresi. Hampir semua generasi millennial dipastikan memiliki akun media sosial sebagai tempat berkomunikasi dan berekspresi. 4. Millennial kurang suka membaca secara konvensional. Bagi generasi ini, tulisan dinilai memusingkan dan membosankan. Generasi millennial bisa dibilang lebih menyukai melihat gambar, apalagi jika menarik dan berwarna. Hobi membaca buku masih tetap ada. Mereka lebih memilih membaca buku online (e-book) untuk tidak perlu repot membawa buku. Sekarang ini, sudah banyak penerbit yang menyediakan format e-book untuk dijual, agar pembaca dapat membaca dalam ponsel pintarnya. 5. Millennial lebih tahu teknologi 
dibanding orangtua mereka. Kini semua serba digital dan online. Generasi ini melihat dunia tidak secara langsung, yaitu dengan berselancar di dunia maya. Generasi millennial adalah generasi yang sangat modern, lebih daripada orang tua mereka. Mereka sering mengajarkan teknologi pada kalangan orangtua. 6. Millennial cenderung tidak loyal namun bekerja efektif. Mereka juga tidak loyal terhadap suatu pekerjaan atau perusahaan, namun lebih loyal terhadap merek. Millennial hidup di era informasi yang menjadikan mereka tumbuh cerdas.

Banyak perusahaan yang mengalami kenaikan pendapatan karena memperkerjakan millennial. 7. Millennial mulai banyak melakukan transaksi secara cashless. Dengan kecanggihan teknologi yang semakin maju ini, generasi millennial pun mulai melakukan transaksi pembelian yang sudah tidak menggunakan uang tunai lagi alias cashless. Generasi ini lebih suka membawa kartu, karena semua pembelian bisa dibayar menggunakan kartu, sehingga lebih praktis, hanya perlu gesek atau tapping. Tantangan Guru Citra dan konsep tentang guru dalam masyarakat kontemporer sangat jauh berbeda dengan konsep masa lampau. Guru masa dahulu berarti orang yang berilmu, yang arif dan bijaksana. Kini guru dilihat sebagai fungsionaris pendidikan yang bertugas mengajar atas dasar kualifikasi keilmuan dan akademis tertentu. Dengan tugas tersebut, guru memperoleh imbalan materi dari negara atau pihak pengelola pendidikan. Dengan demikian, faktor terpenting dalam profesi guru adalah kualifikasi keilmuan dan akademis. Sementara kearifan dan kebijaksanaan yang merupakan sikap dan tingkah laku moral tidak lagi signifikan. Dalam konsep klasik, faktor moral berada di atas kualifikasi keguruan. Berdasarkan penelitian bahwa mayoritas millennial mendapatkan berita bersumber dari media sosial seperti facebook dan twitter, dimana kredibilitas sumber berita sangat sulit untuk diukur.

\section{B. Tantangan Pendidik di Era Millennial}

Kualifikasi akademik seorang guru adalah S1 atau diploma IV. Kompetensi yang harus dimiliki seorang guru adalah kompetensi pedagogik, kompetensi kepribadian, kompetensi social dan kompetensi professional yang diperoleh melalui pendidikan profesi. Masing-masing kompetensi tersebut bila dirinci sebagai berikut: 1 . Memiliki kepribadian sebagai pendidik dengan sub kompetensi a. Memiliki kepribadian mantap dan stabil b. Memiliki kepribadian dewasa c. Memiliki kepribadian arif d. Memiliki kepribadian yang berwibawa e. Memiliki akhlak mulia dan dapat menjadi teladan 2. Memiliki kompetensi pedagogik dengan sub kompetensi a. Memahami peserta didik b. Merancang pembelajaran c. Melaksanakan pembelajaran d. Evaluasi hasil belajar e. Pengembangan peserta didik 3. Memiliki kompetensi profesional sebagai pendidik dengan sub kompetensi: a. Menguasai bidang studi secara luas \& mendalam b. Memahami materi ajar yang ada dalam kurikulum sekolah c. Memahami struktur, konsep, dan metode keilmuan yang menaungi/koheren materi ajar d. Memahami hubungan konsep antar mata-pelajaran terkait e. Menerapkan konsep-konsep keilmuan dalam kehidupan sehari-hari f. Berkomunikasi secara efektif dengan masyarakat 4. Memiliki kompetensi sosial sebagai pendidik.

Tantangan guru di era milenial sangat berat dibanding guru-guru di era terdahulu. Selain menguasai aspek materi keilmuan yang di ajarkan. Guru dituntut memahami teknologi dan selalu menjadi pribadi yang kreatif dan inovatif. Guru harus menjadi role model bagi siswa di generasi millennial, agar siswa memahami 
batasan- batasan teknologi, sehingga terhindar dari pemamfaatan yang salah dalam menggunakan teknologi. Tantangan bagi guru tidak berhenti disini, generasi millennial bukan generasi yang bisa dipaksa-paksa, contoh dengan melarang siswa membawa handphone. Guru di era sekarang harus lebih terbuka dengan pemikiran-pemikiran baru. Guru dituntut mendidik siswa sesuai dengan zamanya. Selama tidak bertentangan dengan norma- norma yang ada tentu hadirnya teknologi tidak perlu dipermasalahkan. Pendekatan persuasif baiknya lebih prioritas dilakukan ketimbang melakukan kebijakan-kebijakan yang terkesan otoriter maupun memaksakan kehendak. Guru bisa memberikan pengertian kepada siswa melalui kebijakan-kebijakan konkret dengan memanfaatkan teknologi dalam pembelajaran, seperti e-learning, atau menggunakan sosial media dll. Siswa justru mendapatkan edukasi bahwa teknologi ketika dimanfaatkan dengan baik justru memiliki dampak yang positif. Secara umum, guru hendaknya memahami perubahan sosial yang ada di era sekarang. Dia tidak berhenti belajar mengenai hal-hal baru. Tantangan global di era sekarang juga beda dengan tantangan global di era dahulu. Apapun langkah dan metode yang dilakukan di sekolah pastinya bertujuan membentuk karakter dan menyiapkan SDM yang berkualitas di Indonesia. Masa depan Indonesia ada didalam ruang kelas yang kita ajar. Tantangan lain pendidikan di era millennial sekarang ini adalah informasi datang lebih cepat, massif dan meluas, sehingga tidak bisa diatasi dengan sekedar pergantian kurikulum. Berapa kali pergantian kurikulum tidak akan pernah mampu mengejar percepatan informasi yang ada. Karena itu, pendekatan guru dan murid dalam berinteraksi akan lebih penting. Perlu keteladanan, membangun kehendak, dan menguatkan - dengan bekal ilmu pengetahuan tentunya - sehingga anak didiknya mampu mengatasi tantangan hidupnya. Tantangan terakhir bagi seorang guru adalah adanya empat keterampilan yang diberikan kepada siswa sejak dini, yaitu melahirkan pemikir, melahirkan komunikator, melahirkan kolaborator, dan melahirkan penemu atau pencipta.

\section{Upaya yang Dilakukan Menghadapi Era Milennial}

Ada beberapa upaya yang harus dilakukan oleh seorang guru menghadapi tantang dalam mendidik generasi millennial ini. 1. Guru-guru yang lahir pada era revolusi industri ketiga harus mengajar mereka yang lahir pada era berikutnya. Tidak bisa tidak, setiap guru wajib mengikuti perkembangan teknologi. Guru tidak boleh lagi gagap teknologi. Komputer dan gawai harus sudah menjadi keseharian para guru. Media sosial dan berbagai sumber informasi maupun sosialisasi juga harus dipahami para guru, sehingga dalam menjalankan profesinya guru akan kaya dengan materi maupun metode pembelajaran. Siswa pun tidak akan menganggap remeh guru. 2. Selain menguasai perkembangan teknologi, guru dituntut juga memahami kecenderungan yang terjadi terkait perubahan teknologi. Dengan mengikuti perkembangan hasil kemajuan teknologi, guru bakal mampu memberikan sudut Untuk melahirkan pemikir, siswa dilatih menyampaikan gagasan aktual, seperti kemacetan, banjir, tawuran. Untuk melahirkan komunikator, siswa dilatih menyampai ide secara lisan dengan baik. Untuk melahirkan kolaborator, siswa dikelompokan berdasarkan ragam kecerdasannya. Untuk melahirkan penemu, siswa dilatih menjadi inovator. Jejen Musfah, Analisis Kebijakan Pendidikan, Prenadamedia, Jakarta, 2016, hal. 84-86. 
Revolusi industri pertama ditandai kemunculan mesin menggantikan tenaga manusia dan hewan. Generasi kedua ditandai dengan kemunculan pembangkit tenaga listrik dan motor pembakaran, hingga muncullah pesawat telepon, mobil, pesawat terbang dan sebagainya. Generasi ketiga ditandai dengan kemunculan teknologi digital dan internet. Pada revolusi industri generasi keempat ditandai dengan kemunculan superkomputer, robot pintar, rekayasa genetika dan perkembangan neuroteknologi yang memungkinkan manusia untuk lebih mengoptimalkan fungsi otak. Muncul pola-pola baru ketika disruptif teknologi hadir begitu cepat dan mengancam keberadaan pola lama pandang, alternatif, bahkan solusi kepada para peserta didik. Di sinilah peran guru yang tidak tergantikan oleh teknologi. Dalam pembelajaran, guru harus dapat menguatkan kemampuan olah pikir, olah rasa, olah hati, dan olah ragawi setiap anak. Hal itu penting agar mereka mampu memaknai, mengolah, menginterpretasi, menyaring berbagai informasi yang ada di sekitar. Guru harus memberikan pembelajaran yang relevan dengan siswa. Belajar menjadi lebih berarti ketika mereka memahami aplikasi praktis informasi yang mereka terima. Konten harus spesifik, ringkas, dan cepat. Generasi millenal harus informasi dan akan mencarinya sendiri jika guru tidak menyajikan apa yang mereka anggap relevan. Karena begitu banyak informasi yang selalu tersedia, mereka tidak merasa perlu belajar setiap hal segera. Sebaliknya, mereka ingin diajari bagaimana dan di mana mereka dapat menemukan apa yang mereka butuhkan. Dalam konteks era digital tentu pendidikan karakter sangat penting. Mengingat, internet adalah belantara yang liar, di mana konten-konten informasi yang positif dan negatif bercampur jadi satu. Hanya fondasi moral yang kuat di dalam diri, dalam arti bisa membedakan mana yang baik dan buruklah yang bisa menjamin masa depan generasi muda Indonesia tetep cerah. Oleh karena itu, seorang guru harus menjaga karakter kebangsaan yang potensial terkikis oleh berbagai ideologi radikalisme yang tidak sesuai dengan Pancasila dan Negara Kesatuan Republik Indonesia (NKRI). Di era globalisasi ini, pendidikan harus melakukan reformasi dan inovasi dalam proses belajar mengajar secara terus menerus. Untuk itu, diperlukan dukungan empirik yang dihasilkan oleh kegiatan penelitian. Oleh karena itu, guru harus paham penelitian.

\section{PENUTUP}

Di era globalisasi dan informasi ini, guru dan dosen mendapatkan tantangan berupa perilaku siswa yang senang berselancar di dunia maya melalui android, gadget atau handphone canggih yang mereka miliki. Perilaku siswa ini ditandai oleh adanya kecendrungan lebih senang membaca melalui handphone ketimbang buku, senang mencari berbagai informasi sendiri tanpa melakukan recheck lebih dahulu, senang mencari teman melalui akun media sosial, dan terkesan individualis. Untuk itu, guru dan dosen dalam pembelajaran harus mampu memanfaatkan Teknologi Informasi, menggunakan metode yang menyenangkan, memperkaya keilmuan dengan berbagai sumber bahan bacaan, dan mampu melakukan penelitian. Demikian uraian yang berkaitan dengan tantangan pendidik di era Millennial dan upaya yang dilakukan untuk mencari solusi terhadap tantangan yang dihadapi guru. 


\section{DAFTAR PUSTAKA}

Azra, A. (2000). Pendidikan Islam, Tradisi dan Modernisasi Menuju Millenium Baru, Cet II. Jakarta: Logos.

Danim, S. (2002). Inovasi Pendidikan: Dalam Upaya Peningkatan Profesionalisme Tenaga Kependidikan. Bandung: Pustaka Setia.

Depdikbud. (1990). Kamus Besar Bahasa Indonesia, Cet. III. In N. Purwanto, Ilmu Pendidikan-Teoritis dan Praktis (p. 1). Jakarta: Balai Pustaka.

Fokusmedia. (2003). Undang-undang RI No. 20 Tahun 2003 tentang Sisdiknas beserta Penjelesannya. Bandung: Fokusmedia.

Indonesia, C. (2018, Oct 18). Pendidikan dan Digitalisasi di Era Milenial. Retrieved from CNN Indonesia

Lestari, R. (2018, Apr 3). Guru BK Kekinian: Solusi Masalah Siswa di Era Millenial. Retrieved from Selasar

Mahardika, D. (2018, Oct 18). Tantangan Menjadi Guru di Era Milenial. Retrieved from Dhinar For Indonesia

Mucharomah, M. (2017). Kisah sebagai Metode Pembentukan dan Pembinaan AKhlak dalam Perspektif al-Qur'an. Jurnal Edukasia Islamika, 204-207.

Mursidin. (2011). Profesionalisme Guru Menurut al-Qur'an, Hadits dan Ahli Pendidikan. Jakarta: Sedaun.

Musfah, J. (2016). Analis Kebijakan Pendidikan. Jakarta: Prenadamedia.

Nata, A. (2005). Filsafat Pendidikan Islam. Jakarta: Gaya Media Pratama.

Purwanto, M. N. (1985). Ilmu Pendidikan Teoritis dan Praktis. Bandung: Remaja Rosdakarya.

Purwekerto, U. M. (2018, Aug 27). Tantangan Guru di Era Milenial. Retrieved from Universitas Muhammadiyah Purwekerto

Puwanto, Y. (2007). Etika Profesi: Psikologi Profetik Perspektif Psikologi Islami, Cet. I. Bandung: Refika Aditama.

Salam, B. (1997). Pengantar Pedagogik (Dasar-dasar Ilmu Mendidik). Jakarta: Rineka Cipta.

Semarang, R. (2018, Oct 18). Tantangan Era Milenial dalam Dunia Pendidikan. Retrieved from Radar Semarang.

Sukmadinata, N. S. (1997). Pengembangan Kurikulum Teori dan Praktek. 1997: Remaja Rosdakarya.

Suwito. (2004). Filsafat Pendidikan Akhlak Ibnu Miskawaih. Yogyakarta: Belukar.

Suyanto, \& Hisyam, D. (2000). Refleksi dan Reformasi Pendidikan di Indoensia Memasuki Milenium III. Yogyakarta: Adicita Karya Nusa.

Tafsir, A. (1982). Ilmu Pendidikan dalam Perspektif Islam. Bandung: Remaja Rosdakarya.

Umbara, C. (2005). Undang-undang Republik Indonesia Nomor 14 Tahun 2005 tentang Guru dan Dosen Bab IV Pasal 10.

Umbara, C. (2006). Undang-undang Republik Indonesia Nomor 14 Tahun 2005 Tentang Guru dan Dosen Bab IV, Pasal *. Bandung.

Yamin, M. (2007). Profesionalisasi Guru dan Implementasi KTSP. Jakarta: Gaung Persada Press. 